\title{
Analyzing the Reality of the Iraqi Stock Exchange in Light of Financial Globalization
}

\author{
*Professor.Faris Karim prihi, **Lecturer.qahtan Lafta Atiyah \\ *College of Administration and Economics, Baghdad University \\ **College of Business Economics, Al-Nahrain University
}

DOI: $10.37648 /$ ijrssh.v10i04.028

Received:10 ${ }^{\text {th }}$ November, 2020; Accepted:08 ${ }^{\text {th }}$ December, 2020; Published: 10th December, 2020

\begin{abstract}
In light of the financial globalization, the Iraqi Stock Exchange faces real challenges at both local and international levels which in turn reflected on the overall reality of economy and imposed the necessity of creating fundamental changes in terms of form and content. From this point stems the problem of the research regarding the ability of the Iraqi Stock Exchange to adopt the financial changes and transformations imposed by the financial globalization in light of the weakness of the economic structure and its position among the international economy. This research starts from the hypothesis that the Iraqi market for securities, in light of the financial globalization, has a great and an important role within the economic field through its role in stimulating the economic growth, and impacting the economic performance in light of the financial transformations imposed by the financial globalization. The study revealed that the financial globalization is an inevitable phenomenon that strongly imposes itself aiming to international integration and integration with the world which reflected its shadows on the increases in the number of shares traded, and the occurrence of some changes within the actions of the Iraqi market for securities. However, the market's role still limited to the national economy due to several problems such as the private sector weak contribution within the market, in addition to the novelty of the Iraqi experience regarding the work and actions of securities' markets, the absence of investment awareness, the low income and the lack for a successful policy that encourages investment, as well as the low rates of economic growth due to the economic and political instability the country witnesses.
\end{abstract}

\section{INTRODUCTION:}

The globalization of the Stock Exchange phenomenon and the sequences of IT and communication revolution has imposed real challenges on both local and international levels which in turn reflected on the overall economic reality and imposed the necessity of creating fundamental changes in terms of form and content with the spread of this phenomenon to achieve economic stability and growth. To keep pace with the development and upgrading the reality, it has become necessary for the Arab countries including Iraq to face the challenges and to keep in pace with the successive developments using all the possible advanced scientific methods in addition to evaluating the current status using scientific methods that assist to achieve the appropriate and correct understanding, and the sound analysis of the phenomenon of Arab markets of securities and their potentials globalization.

Hence, our aim of analyze the reality of the Iraqi Stock Exchange in light of the financial globalization is to stand on the Iraqi Stock Exchange' performance in light of the financial globalization in order to reinforce a greater understanding for the financial globalization and its effect on the Iraqi Stock Exchange, and to acquire a realistic look at the internal climate and the current developments 
to face foreign markets' challenges that imposed a great competition on the Arab markets among which the Iraqi market, and to strengthening their ability to attract more investments, in particular, the Arab funds invested abroad.

\section{Significance of the Research:}

- To monitor the current status of the Iraqi Stock Exchange and its ability and role in attracting capitals and recycling them to face the financial globalization challenges and the ability to transform these challenges into a real opportunity for growth and development.

- To clarify what has the Iraqi market for securities achieved of financial resources in reinforcing investments which in turn reflected on the economic growth.

- To clarify the importance of the securities' markets for the Iraqi economy and to reinforce the economic growth through increasing the private sector contribution within the economic activity.

\section{Research Problem:}

The problem of the research is represented by the Iraqi market for securities' weak ability to adopt to the transformations imposed by the financial globalization in light of the Iraqi weak economic structure and its position within the global economy.

\section{Hypothesis of the Research:}

This research is based on a hypothesis which states that "the Iraqi Stock Exchange, in light of the financial globalization, can play an important role in the economic field through its role in stimulating the economic growth, and influencing the economic performance in light of the financial transformations imposed by the financial globalization.

\section{Research Objectives:}

- Analyzing the reality of the Iraqi market for securities in light of the financial globalization and identifying the reforms it has witnessed and the obstacles it faces.

- Identifying the extent of the Iraqi market for securities in keeping pace with developments witnessed by the international financial system.

- Identifying the potential challenges for the Iraqi market for securities in light of the financial globalization and to benefit from the opportunities they may offer.

\section{Research Limitations:}

* Time limitations : the research covers the period 20062018.

*Spatial limitations: the Iraqi market for securities.

1ST REQUIREMENT: THE CONCEPT OF FINANCIAL GLOBALIZATION AND THE

\section{REASONS FOR ITS ADVANCEMENT AND EXPANSION}

$\underline{1^{\text {st }} \text { : the Financial Globalization Concept: }}$

It is not easy to determine or have a stable and an ultimate concept for globalization as it is polysemy and multisemantic, situations, opinions and points of views, in addition, there are numerous questions about globalization, accordingly the diagnosis of this phenomenon and the determination of its content, what it is, its objectives, means, its motives, and its history is not an easy matter as it has come as a term for academic uses and it was circulated among various circles and gained their attention and each party has taken it and used it based on its own reference and understanding for it.

Some may view the concept of globalization in its content as not more than one sentence, namely the transitional economy for the national sovereignty for the purpose of creating appropriate and strong opportunities for a group of people who are not affiliated with the capitalist center wandering around the world leaving a wide gap in international economic relations through the liberalization of exchange and the exercise of selective attraction in directing foreign investment and the use of modern technology (Saleh, 2002, page 15 ). Some others view globalization in itsfundamentally a degree in the history of capitalist development and is thus an objective phenomenon that opens horizons and expands the vital field of capitalism in the twenty-first century (Dantas, 2002, p. 103).

Many authors indicate globalization with various ways as a complex mixture of economic, technological, social, cultural, and political forces. Globalization often is used to indicate the economic globalization, that is , integrating national economies within the international economy through transnational trade, direct foreign investment, capital flows, and migration. Thus, economic globalization is a dynamic, interconnected, and multi dimensions process of economic integration where national resources are more and more internationally mobile while national economies become increasingly interconnected. Thus, this process indicates the reduction and removal of barriers between national borders, in order to facilitate the flow of goods, capital, services and labor (Al-Nuaimi, 2002, p. 54).

In order to upgrade the private via the public, and based on the aforementioned, a group of financial globalization concepts can be addressed and regarded as a part of 
economic globalization represented by the movement of capital between various markets with the easiest and less expensive ways for the purposes of funding and investment ( Ala'sadi, 2004, p26), which is understood as integrating the local financial system for the country with the international financial markets and institutions ( Mendoza. K, 2009). Others define financial globalization as a combined phenomenon of liberating financial systems and integration within international securities' markets intended to achieve interdependence at the international level and achieving integration by influencing countries sovereignty and dissolving borders and establishing international relations based on trade and international financial transactions' liberalization as well as national markets' openness and linking them with the international market ( Schmukler. S, 2004).

Based on the aforementioned, globalization is a phenomenon that aims to international integration and integration with the world and accordingly, it can be viewed as one of the capitalist most important projects that no longer stand behind the door seeking permission to enter, but it really has started since years to act and is not just a concept any more but a daily practice and behavior and a continuous process that is constantly growing and developing.

$\underline{2}^{\text {nd }}$ : Factors Assisting in the Financial Globalization

\section{Development:}

The phenomenon of globalization has narrowed the world and expanded its horizons with the increased interconnection with the global economy reaching the integration of national economies represented by the significant increase in foreign investments' flows due to the removal of restrictions and controls on the capital movement and the removal of monetary restrictions on external payments, followinga policy of restructuring and privatization, with the exacerbation of financial speculation in convertible currencies, indirect investments, and other means of debt denominated in convertible currencies, and this phenomenon would not have burst into force unless there was a fundamental change in the parameters of the economic structure through the transition to a new economic phase. It is characterized by the emergence of a financial "globalized" system in which transactions are made through shares, bonds, rights and financial options, whereby wealth is transferred to the world and the barriers do not stop in the sense of penetrating national borders. This expansion and rapid integration of global financial markets is attributed to several factors that worked in an integrated system towards one direction. And she (Johnson, 1998, p.23): 1Massive flow of both trade and investment ( direct and indirect):

Financial Globalization represents a new stage of capital accumulation at the international level, it initiated a huge increase in the size of investment flow and trade, expanding in the international credit, monetary flow, and public and private debt ( Panit, 1998). From this point, some asserts that the global integration wasn't pushed by policy or the internet or the World Trade Organization, or even that financial globalization basically moved through the financial expands but, trade and investment are the most important factors leading to move toward financial globalization. Thus, by the mixture of two factors that are the small size of the world due to the communication and transportation revolution and investment flow toward every spot in the world, in addition to the external trade expansion, the global economy became not only characterized by the freedom of trade of goods and services but more than this the freedom in capital movements, accordingly, massive flows of each of trade and investment led to a financially interconnected world and a deeper degree of financial integration.

2- Development of communication, information, and transportation technology:

Perhaps the most important consequence of the development in communications and information technology is what resulted from this convergence and integration between the various parts of the world, so that some started talking about a "universal or global village" and then emerged the Internet to represent a new decentralized means of communication, dialogue and exchange between individuals and institutions outside borders and across continents. Through it, not only information, knowledge and correspondence are circulated, but it has also become a marketplace for contracting between sellers and investors from different countries of the world. Consequently, technical progress, especially in the field of communication and information, helped the growth and the spread of financial globalization more quickly, and through this technical progress the obstacle of time and space barriers between the various national financial markets was overcome, and the cost of communications and transactions decreased, which affected the increase in the speed of movement of capital from Market to Market (Kennedy, 1993, p.73). Besides, it has become easier to know the latest news of 
price movement in various international financial markets and compare them in order to make appropriate investment decisions in the shortest possible time (Sufyan, 2004).

\section{3- Capitalism natural tendency towards control:}

Financial globalization could not grow and accelerate without coinciding the growth of financial capitalism. The latter has grown through the growth and development of the financial services industry, with its banking and nonbanking structure, such as commercial banks, insurance companies, investment funds, ... etc. Capitalism has also become of a rentier pure nature, and this is evident through its employment of capital to invest it, and it also achieves more rent in securities than it achieves profits in productive projects. This reflects that the movement of capital in the global markets is no longer linked to the movement of international trade, but rather has its own entity, mechanisms and cycle. The growth of financial capitalism can be linked to what has been called the "symbolic economy" that is driven by global stock market indexes, and is affected by changes in interest rates, exchange rates, balance of payments, changes in the general level of prices, and unemployment rates (AlBeblawy, 1998, p 122-123).

\section{4- The role of international and regional economic and political mechanisms ( Alsalm, 2003,p83) :}

International institutions constitute the main and decisive element in the system of financial globalization through the mechanisms of their work and the binding rules they establish. It can be said that the global economic system has begun to form in the aftermath of the Second World War, as there were no actual international institutions before this date, and the importance of these institutions is evident through the functions and role assigned to each of them and the basic concepts on which they are based in their work. Thus, the three institutions "the International Monetary Fund, the World Bank and the World Trade Organization", in particular, constitute the central leadership of the global economic system alongside the increasing role of transnational companies and the role of financial speculation with the increasing movement of progress. In addition to these three most effective organizations, there are many international active organizations with influence and effectiveness, such as the Organization for Economic Cooperation and Development, and non-governmental organizations such as the Club of Rome and the Davos Forum and dozens of institutions and research institutes that have been publishing unified concepts in order to coordinate plans and strategies to push the march of financial globalization, its mechanisms, and how to ensure its continuation in the field of service liberalization, the removal of restrictions against foreign investments (direct and indirect), protection of intellectual property rights, removal of quantitative restrictions that limit freedom of trade, as well as reducing customs tariffs and securing market access in light of new changes and developments (AlJumaili, 20002, p.7).

\section{5- The role of international- activity companies (transnational):}

Financial globalization represents a qualitative leap in the global economic history, not in terms of linking different economies, which are now more interconnected, or in terms of global trade size, which has exceeded all economic figures, or in terms of foreign investments that have reached unprecedented levels. But rather at the level of re-establishing the rules, institutions and structure of this system, that is, the transfer of the global economic center of gravity to companies, institutions and economic blocs is the essence of financial globalization.

\section{6-Emergence of the new financial tools (Financial Innovation):}

There is no doubt that financial globalization and its effective relationships and forces, as well as new financial tools, such as swaps, options and futures, in addition to the traditional tools traded in the financial markets (stocks and bonds) have reflected a financial development. The global economy is an open system that knows no borders and no restrictions towards a unified international market. The reluctance of cross-border transactions has increased and diversified, and capital flows between countries have increased (Al-Assarj, 2002, p 39-44).

\section{7- Growth of bond market:}

Bonds, in particular, emerge as one of the most important financial instruments in global financial markets. Therefore, an important part of the acceleration of globalization of financial markets is due to the great growth that has occurred in bond issuances and circulation 
in those markets, especially government bonds, which are the backbone of the bond market in general. It is worth to note that there are important factors helped in the great growth of the bond market, and these include the fight against inflation, the preference of governments to finance their budget deficits through bonds, resorting to external financing, and progress in financial intermediation in these markets.

\section{8-Restructuring of the financial services industry:}

What has also increased the pace of financial globalization is the occurrence of major changes in the banking services industry and its restructuring. The circle of banks 'business has expanded locally and internationally, especially after the waves of financial liberalization that it has witnessed, as financial institutions have tended to perform banking and financial services that they had not previously performed, which resulted in diversifying the sources of banks' funds and diversifying their methods of use, in addition, non-banking financial institutions were also registered in the field of financial services, such as insurance companies, pension funds, investment funds ... etc., in addition to the spread of purchases and mergers between financial institutions (AlHamid, 2001, p. 36).

\section{8-Privatization:}

The process of privatizing public sector companies and institutions and some public services has played an important role in expanding financial globalization, especially with the increase in domestic and international financial liberalization measures in countries that have adopted privatization programs, especially in developing countries where privatization programs have accelerated operations, which allowed foreign investors the possibility of ownership.

\section{ND REQUIREMENT : TRANSMISSION CHANNELS OF THE FINANCIAL GLOBALIZATION IMPACT ON ECONOMIC GROWTH}

Financial globalization is a two-dimensional process. The first is the increasing size of cross-border financial transactions, and the other is the sequence of institutional and legal reforms implemented to liberalize international capital and national financial systems that lead to a financially interconnected world and a deeper degree of financial integration that can bring significant benefits to the development of the financial system, or pose challenges to policymakers (Schmukler, 2004).

The indirect benefits of financial globalization are likely to be important in the following key areas:

- Financial sector development: that international financial flows are an important incentive for the development of local financial markets, as the more foreign banks exist in a country, the better are the quality of their financial services and the greater the efficiency of financial intermediation. Regarding capital stock markets, the entry of foreigners increases efficiency and stock markets tend to become larger and more liquid after the liberalization of stock markets (Sergio L. Schmukler, 2001). Thus, the development of the financial sector, in particular, is one of the main factors determining the level of growth and stability that financial globalization can achieve. The more developed the financial sector in a country, the greater are the benefits of capital flows to growth and the lower the country's exposure to crisis risk, through both direct and indirect channels.

- Institutional quality: Financial globalization has also prompted a number of countries to adjust their corporate governance structures in response to foreign competition and the demands of international investors. In addition, foreign direct investment in the financial sector from wellregulated source countries tends to support institutional development and governance in emerging market economies.

- Macroeconomic policies: what must be also imposed is the capital account liberalization by increasing the potential costs associated with bad policies and enhancing the benefits associated with good policies, and also, discipline on macroeconomic policies specifically must be imposed, because liberalizing the capital account makes the country more vulnerable to sudden shifts in investor sentiment. The state is obligated to improve macroeconomic policies as a means to mitigate the likelihood of such shifts and their harmful effects.

-The quality of institutions : plays an important role in determining not only the results of financial integration but the actual level of integration, which strongly affect the formation of flows to the economy, which reflect its 
shadows on the macroeconomic results towards foreign direct investment and portfolio stock flows, which leads to achieving more additional benefits of integration Financial.

-Trade integration : trade integration that improves the cost-benefit option associated with financial integration, as well as reduces the likelihood of crises associated with financial openness and reduces the costs of these crises when they occur. Therefore, recent studies support the call made by the early literature that advocated the position of trade liberalization before the capital account liberalization (M. Ayhan Kose, 2007).

According to aforementioned, the interaction between financial globalization and this group of main domains for indirect benefits determines the economic growth results ( Figure 1 ).

\section{Figure (1): Channels of financial globalization effect transmission on economic growth}

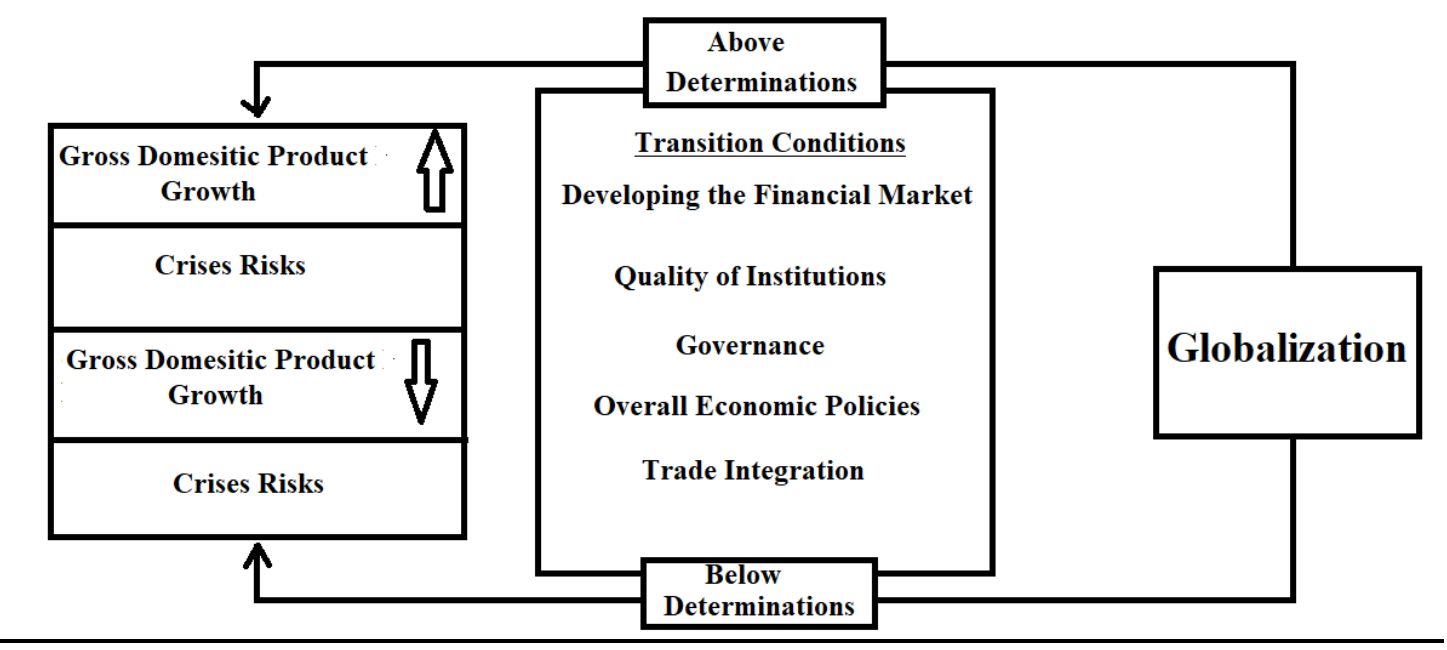

Resource: M. Ayhan Kose, Eswar Prasad, Kenneth Rogoff, and Shang-Jin Wei , Financial Globalization: Beyond the Blame Game, This article is based on IMF Working Paper No. 06/189, "Financial Globalization: A Reappraisal.", Finance and development, March 2007, Volume 44, Number 1

Opportunities achieved by financial globalization can be clarified as follows ( Ramadan, 2018, p17):

1- Financial globalization helps in accessing international capital markets, and it would help cover deficiencies in domestic savings, which raises national investment rates and rates of economic growth, and develops economic performance by obtaining the necessary financing to make various investments.

2- Financial globalization in increasing capital flows leads to valuable opportunities to diversify financial portfoliosand sharing risks and international trade, as having debts owed by foreign countries allows families and institutions to protect themselves against the effects of the unified country's vulnerability to the economic turmoil that might be exposed to the unified country, and it also gives the ability for institutions to immunize themselves against cost and productivity shocks in their countries by virtue of the coverage provided by their investments in the various branches or factors that affect their countries. Consequently, diversification and deepening of investment opportunities in the financial markets to encourage foreign investment.

3 - It would reduce its excessive dependence on foreign debt. The increase in the flow of foreign currencies has positive effects in terms of increasing levels of foreign exchange reserves, and it would lead to a decrease in resorting to banks and government loans, which helps to limit the growth of foreign debt.

4- The openness of financial markets is considered an indication of the country's commitment to good and rational economic policies, as local and foreign investors can punish the country in the event of a deterioration of its political climate, by the sudden exit of their capital and this is a strong incentive and pressure on all policy makers to adopt sound policies at all levels. 
5- Financial resources' flow towards the country would be reflected positively on its various sectors through reducing funding cost as governments can resort to international financial markets and offer debt securities for subscription wherever the rate of external interest is low which enables them to cover the deficits in local resources, and the same is true for the private sector which can resort to external financing if borrowing in foreign currency is more attractive or less expensive in terms of interest rates compared to borrowing denominated in the national currency.

6- Market mechanisms would lead to positive real interest rates without exaggeration, which would allow an increase in the size of deposits with the banking sector, due to the recovery of significant portions of the savings circulating outside the department of the formal financial sector, and thus an increase in national savings rates. Positive real interest rates are a strong incentive for investors to borrow from banks and establish productive projects and activities that contribute to creating a surplus in value and building strong pillars for a real economy, and here the financial intermediation of the banking system will increase in quantity and quality.

Accordingly, we cannot deny the benefits of financial globalization, which have a shadow over economic growth. But at the same time, financial globalization has its dark side, and thus the risks of financial globalization can be explained in the followings (Al-Saad, 2015, pages 511-534):

1- If a country opens its capital account without some basic supporting conditions, the country is more vulnerable to the sudden cessation of capital inflows.

2- Since the financial markets in the world were not connected due to financial globalization, the occurrence of a problem in one country of the world, it will be in an uncontrollable manner in other countries of the world.

3- Financial globalization carries several risks that threaten economic stability, as when financial markets integration achieves opportunities to run the real economic activity and growth, there may be reverse results for what is expected as assets' prices may exceed fundamentals during this period which leads to extreme fluctuations that threaten the financial system stability as whole and these fluctuations reflect their shadows on not perfectly allocating capital .

4- The highly increased financial risk trading in the form of securities among institutions and investors makes it hard to determine the anticipated weaknesses or to estimate the size of these risks as investment in securities portfolios are characterized by being a catalyst for reverse flow of capital in short periods as compared to other forms of investment which may leads to un desired fluctuations and sometimes to extreme fluctuations in interest prices, exchange prices, or both which leads toa misalignment at the level of payments' balance and makes investors sell their assets and holdings of local stocks for purchasing foreign currencies in addition to the negative effect on share prices which will decline.

5-The risks of marginalization that developing countries, including Arab countries in particular, may be exposed to as a result of the astonishing speed with which financial globalization is proceeding, which is characterized by a set of relationships, factors and forces that move on the global level beyond the geographical borders of states and are difficult to control, backed by international obligations, using mechanisms multiple and generating effects and results that extend beyond the country to the global level.

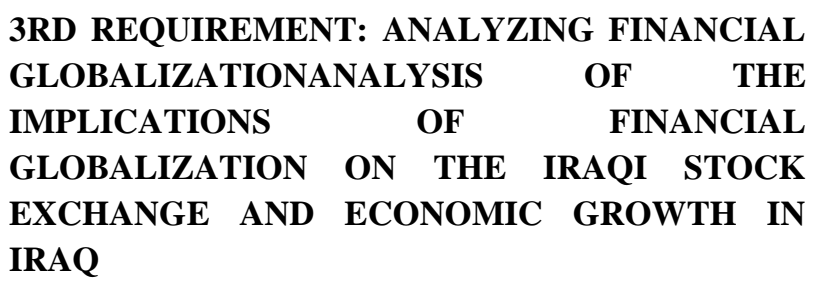

\section{1st : A historical overview of the Iraq Stock Exchange} :

The idea of establishing the financial market in Iraq has experienced several events and development which reflected on the development of the Iraqi stock exchange, the most important events witnessed by the Iraqi stock exchange can be summarized as follows :

1-In 1921, Iraq knew the first steps in the emergence of the stock market, as in this year the first joint stock company was established based on the Indian Companies Law issued in 1913 that was applied in Iraq after the British occupation, and the stock exchange law No 65 was issued in Iraq in 1936, which stipulated the establishment of a stock exchange for the main merchandise trade, and this law continued for two years, then it was suspended in 1938. Thus, this experience did not get an adequate opportunity to spread the basics of working in the stock exchange in Iraq (Al-Iraqiya, Issue Date 31/8/1936). 
2-In 1943, Trade Law No. (60) was issued, which included matters related to the establishment of the stock exchange, especially in Articles (99_102), on the basis of which the work of the market was organized, the identification of the employees working in it and the restriction of dealing with intermediaries, but the practical application of this matter was not possible as shares were traded in Iraq between the seller and the buyer directly and registered with the company concerned with the shares, but as a result of the increase in the number of companies and then the number of traded shares, several brokerage offices were established in 1955( 4 offices), which were concentrated on Al-Samawa'l Street in Baghdad*. And as a result of the growing movement of establishing jointstock companies after that and the activity of the brokerag offices, the circulation expanded and the Baghdad Chamber of Commerce started publishing the accurate prices of the traded shares within its weekly bulletin. Also, one of the offices tried in 1956 to use the method of public bidding in the sale and purchase of shares and the offices continued to operate until 1964 as their activity stagnated due to the issuance of nationalization decisions in the aforementioned year, then it stopped permanently (Al-Iraqiya, Issue Date: 08-23-1943).

3- In 1970, the Iraqi Trade Law No. 149 of 1970 (AlIraqiya, Date Issue: 24-04-1971) was issued, as the Iraqi legislator began to realize the extent of the need to establish a stock market. This law includes three articles that authorized the establishment of a stock market based on a system issued by the Minister of Economy, but the reality has not witnessed the emergence of such a market; this is because it did not meet the full attention and support of the state, which led to the closing of the market and the emergence of the industrial bank role. In 1975 the Industrial Bank took the initiative to establish an office for the sale and purchase of shares within its administrative apparatus, and work continued with that until the issuance of Baghdad Stock Exchange Law No. 24 of 1991, and this law includes eleven chapters and fifty-two articles (Al-Sawaf, 2004, p 108).

4- On (3/23/1992) the Baghdad Market was officially opened, and the market enjoys a moral personality, financial and administrative independence, and is of a general non-profit benefit, and the market's focus was on the regulatory side in order to transform the market from its unorganized state to an organized market in which investment tools are diversified In order to attract savings in order to support the national economy, however, converting these goals into a tangible reality ran into many obstacles, including the fact that the establishment of the market was in an inappropriate economic environment (Majeed, 2002, p 208), and on March 19, 2003, due to the circumstances of the war on Iraq, it was closed by decision of its board of directors.

5- On April 18, 2004, the Iraq Stock Exchange was established according to Provisional Law No. 74 issued by the Coalition Provisional Authority. This law came with a new structure for the financial market with two independent entities. The General Securities Commission, a governmental institution linked to the Council of Ministers, whose mission is to regulate and control securities trading activities by issuing instructions and rules and monitoring disclosure in joint-stock companies and stock brokerage companies, and the Iraq Stock Exchange, which started its activities in the first trading session on June 24, 2004 ( Finance, Third Annual Report, 2006, page 7), which is an economic market with financial and administrative independence not linked to any party, managed by a board consisting of nine members representing various economic sectors of the investment sector called the Board of Governors, working under the supervision of the Iraqi Stock Exchange Commission, in order to organize and train its members The companies listed on the market in a manner commensurate with the goal of protecting and enhancing investor confidence in it, in addition to promoting the interests of investors in a free market that is trusted, efficient, competitive and transparent, as well as organizing and simplifying stock exchange transactions in a fair, efficient and regular manner, including clearing and settlement operations and whatever related to buying Selling stocks, and thus developing the financial market in Iraq to serve the national economy, in accordance with the rules and instructions in order to attract indirect national and foreign investments in financial instruments in order to achieve the goals of increasing capital formation in the economy and to employ private sector capital in joint-stock companies using electronic systems, provided that the financial and share settlement are done in an regulated manner, and the law and bylaw regulating its duties and tasks. 
$2^{\text {nd }}$ : Analyzing the implications of financial globalization on the indexes of the development of the Iraqi stock exchange:

Through analyzing the data related to the development of the Iraqi stock exchange indicators (table 1 ), which include the prices index, market value,volume of trading and the number of listed companies in addition to the role of foreign investment in the Iraq Stock Exchange were as follows

1-The size of foreign investment reached 17,121 million Iraqi dinars in 2007 and this year was the beginning of foreign trading in the Iraqi market after the activation of the Foreign Investment Law No. 13 of 2006, which allowed the entry of foreign capital into the country and the trading of shares of various foreign companies, which was reflected in the increase in trading size to reach one million Iraqi dinars in 2008 with a change rate of $44.4 \%$ (Isawi, 2016, pa 77) with an increase in the Iraq Market Index by 33,072 points, the index closed at the last session of 2008 at 58.36 points, compared to 25,288 points in 2006, Consequently, this rise was reflected in the Iraq Stock Exchange Index on the rise in the market value to reach 2.3 trillion, an increase of 334 million compared to 1.9 trillion in 2006, with the number of shares traded rising to 151 billion shares and a trading value of 301 billion dinars in 2008, compared to 58 million shares traded in 2006, with a circulation value of 147 billion dinars, in addition to the increase in the number of listed companies to 94 in 2008 .

2-During the year 2009 trading in the Iraq Stock Exchange trading moved into electronic trading for the first time in the history of Iraq on Sunday session 19/4/2009 and the plastic panels were replaced by electronic trading stations (workstations) at the market headquarters and also at 47 locations of a brokerage company outside the market building, and trading via the WAN network in addition to the stock exchange commission website that monitors trading, and the number of sessions became five sessions per week according to the Horizon electronic trading system, and the ownership transfer process became noticeable according to the Equator system, and financial settlements take place immediately after the session $\mathrm{T}+0$-that is, financial and equity settlement takes place at the same time- (Financial The annual report 2012, page 1), which is reflected in the development of the market indexes, as the Iraqi market index for traded stock prices closed in the last session of 2009 at 100.86 points, and the index closed in the last session of 2010 at 100.98 points, up from its closing in 2009 by $0.12 \%$. This was reflected in the increase in the market value by $10 \%$ to reach 3446 billion dinars in 2010 compared to 3125 billion dinars in 2009 , with the increase in the number of shares traded by $21 \%$ to reach 255.6 billion shares, worth 400 billion in 2010 , compared to 211 billion shares, with a value of 411 billion dinars in 2009, and the total value of shares purchased by foreign investors from the shares of traded companies during the year 2010 amounted to 62.888 million dinars, so the value of the shares sold by them amounted to 8.319 billion dinars in 2010, and thus the value of the shares sold by them amounted to 8.319 billion dinars in 2010, and thus the value of the shares sold by them amounted to 8.319 billion dinars in 2010. While the number of companies listed in the Iraq market reached 87 companies at the end of 2010 compared to 85 companies listed at the end of 2009 .

3- During the year 2013 the Iraq Stock Exchange launched a new record * (market index) ISX Price Index, as since February 2013, canceled and poorly traded companies that were in the previous sample were excluded and a new company representing the telecommunications sector was added. The number of traded shares reached (876) billion shares worth (2.8) trillion dinars, and the market value of shares listed on the market amounted to 11,476 trillion dinars, and the value of shares purchased by foreign investors reached (1149) billion dinars, while the value of the shares sold by them were (169.7) billion dinars, thus the net foreign investment was 980 billion dinars.

4- In 2015, the Iraq Stock Exchange launched the new electronic trading system X-Stream. This system calculates the ISX60 market index in each session for a sample of (60) listed joint stock companies compared to their prices for the base session, then compares the prices of the current session compared to the previous session. The value of the index is a record value for indicating the directional market movement (Financial, 2015, page 6). The ISX60 market index closed at 995.944 points in the first trading session, and closed at 730.56 points in the last session of the year 2015, achieving a decrease of $26 \%$, and this is due to the devastation caused by the ISIS terrorism which has affected the infrastructure and the productive

\section{INTERNATIONAL JOURNAL OF RESEARCH IN SOCIAL SCIENCES AND HUMANITIES}


material capital components, and the size of the population has become under poverty estimated at about $30 \%$, with the decline of the Iraqi economy indicators after the great decline in oil prices in 2014 and 2015 and the transformation of the economy from a surplus economy to a deficit economy, at a time when many of the public sector companies were losing out and did not change the pattern of their plans, and thus their shadows were reflected in the decrease in the value of shares purchased by foreigners by $34 \%$ compared to 2014 , which was reflected in turn on the net foreign investment to indicate a negative value, with a decrease in the number of shares traded by $17 \%$ to reach 619 billion shares, and a decrease in the market value by $2 \%$ compared to 2014 .

5- With the continuing impact of global oil prices on the indicators of the Iraqi economy, as it is a unilateral economy in its dependence on oil production and exports to achieve the largest proportion of GDP resources and the general budget deficit, with the requirements of the war on terrorist gangs and the liberation of the land, which was reflected in the delay in the movement of funds intended for purchase by foreigners through foreign and Iraqi banks, which affected the volume of liquidity and its polarization towards trading and influence in attracting new investors to the market, and accordingly, the ISX60 market index closed at 510.12 points in the last session of 2018 and compared to 2017 , the index decreased by $12 \%$, with a decrease in the number of traded shares by $31 \%$ to reach 832 billion shares in 2018, and thus reflected on the decrease in the value of traded shares by $48 \%$ to reach 466 billion dinars compared with the year 2017 amounting to 900 billion dinars, and as a result, the total value of the shares purchased by foreign investors from shares of publicly traded companies during the year 2018 was 52.631 billion, while the value of shares sold by them amounted to 34.457 billion dinars, thus the net foreign investment increased by 18.174 billion for the year 2018 , compared to 15.508 billion dinars for the year 2017, as well as the increase in the number of companies listed in the Iraqi market to reach 104 companies by the end of 2018 compared to 101 listed companies by the end of 2017. Accordingly, the market value is noticed to increase by $6 \%$, to reach 11,350 trillion dinars, compared to 2017 .

Hence, we notice that due to the activation of the Foreign Investment Law No. 13 of 2006, which allowed the entry of foreign capital into the country, the circulation of shares of various foreign companies, the implementation of electronic trading activity and the activation of the market database, all of these reasons has led to an increase in the market value during the period 2006-2018, which reflected their shadows on the increase in the number of shares traded, which is a natural condition in the market as a result of the increase in the number of traded companies, and despite the follow-up of financial reform steps, the increase in the market value, the number of companies and stocks, and some developments in the functioning of the stock market, the market's role is still limited in the national economy due to the weak participation of the private sector in the market, as well as the weak governance procedures that enhance investor confidence, and the weak competitiveness of Iraqi products, in addition to state control and semi-direct supervision of the private sector through a network of instructions and controls that the state sets towards the private sector, which prevented the private sector to establish its role in mobilizing individual savings in order to invest them in large investment projects, in addition to the murkiness of the investment climate and widespread mistrust in the country the state directed the private sector.

Also, the companies listed in the Iraq Stock Exchange, which reach (104) companies and the market value of them (11) trillion dinars, are weak companies, and the highest percentage in trading is for the banking sector, where the number of shares in this sector is 7.8 trillion shares constituting $72 \%$ of the market, in other words, trading is concentrated in a small number of listed companies and this is an indication of the weakness of the effectiveness and activity of any financial market, and this does not help in attracting large numbers of foreign investors, in addition to the instability that made it possible for the investor to make a sudden decision to leave so that this type of investment is often called hot money.

The Iraqi stock exchange also witnessed weakness in the performance of the productive, industrial and agricultural sectors in contrast to the dominance of the banking and communications sector in terms of trading size and the number of shares in the Iraqi stock change, as well as the weak performance of the banking sector, as banking activity is concentrated in external transfers and trade finance, in addition to the absence of market-making institutions through investment funds, issuance houses,

\section{INTERNATIONAL JOURNAL OF RESEARCH IN SOCIAL SCIENCES AND HUMANITIES}


and banks that operate according to the concept of comprehensive banking that contribute to building jointstock companies in cooperation with the private sector.

$\underline{\text { Table (1) : Development of Iraqi Stock Exchange' Indexes }}$

\begin{tabular}{|l|l|l|l|l|l|l|l|l|}
\hline Year & $\begin{array}{l}\text { Local } \\
\text { price } \\
\text { indexes } \\
\text { (Point }\end{array}$ & $\begin{array}{l}\text { Market } \\
\text { value } \\
\text { (trillion } \\
\text { dinars })\end{array}$ & $\begin{array}{l}\text { Number } \\
\text { of traded } \\
\text { name } \\
\text { (billion } \\
\text { shares) }\end{array}$ & $\begin{array}{l}\text { Trading } \\
\text { size } \\
\text { (billion } \\
\text { dinars) }\end{array}$ & $\begin{array}{l}\text { Net } \\
\text { investment } \\
\text { of } \\
\text { foreigners } \\
\text { (billion } \\
\text { dinars) }\end{array}$ & $\begin{array}{l}\text { Number of } \\
\text { listed } \\
\text { companies }\end{array}$ & $\begin{array}{l}\text { The value } \\
\text { of shares } \\
\text { purchased } \\
\text { Billion } \\
\text { dinars( }\end{array}$ & $\begin{array}{l}\text { Value } \\
\text { of } \\
\text { shares } \\
\text { sold } \\
\text { (billion } \\
\text { dinars)( }\end{array}$ \\
\hline 2006 & 25.288 & 1.949 & 0.058 & 147 & - & 93 & - & - \\
\hline 2007 & 34.59 & 2.129 & 153 & 427 & - & 94 & - & - \\
\hline 2008 & 58.36 & 2.283 & 151 & 301 & - & 94 & - & - \\
\hline 2009 & 100.86 & 3.125 & 211.3 & 412 & 18.362 & 91 & 19.372 & 1.010 \\
\hline 2010 & 100.98 & 3.446 & 255.6 & 400 & 54.569 & 85 & 62.888 & 8.319 \\
\hline 2011 & 136.03 & 4.930 & 492 & 941 & 127.652 & 87 & 176.499 & 48.847 \\
\hline 2012 & 125.02 & 5.597 & 626 & 894 & -2.037 & 85 & 54.048 & 56.085 \\
\hline 2013 & 113.15 & 11.476 & 876 & 2845 & 980.154 & 83 & 1149.808 & 169.654 \\
\hline 2014 & 92 & 9.546 & 746 & 901 & 30.019 & 83 & 112.548 & 82.529 \\
\hline 2015 & 730.56 & 9.265 & 619 & 495 & -40.299 & 98 & 73.203 & 113.502 \\
\hline 2016 & 649.48 & 9.355 & 1038 & 516 & 15.261 & 97 & 53.835 & 38.574 \\
\hline 2017 & 580.54 & 10.721 & 1215 & 900 & 15.508 & 101 & 62.077 & 46.569 \\
\hline 2018 & 510.12 & 11.350 & 832 & 466 & 18.174 & 104 & 52.631 & 34.457 \\
\hline
\end{tabular}

Resource: The Iraqi Stock Exchange-Annual Report - Various Years

$3^{\text {rd: }}$ The reflection of financial globalization on economic growth in Iraq and the financial depth of the Iraq Stock Exchange:

By reading the data on the development of the gross domestic product at current prices and the financial depth of the Iraq Stock Exchange included in Table (2), the followings are illustrated:

1-The gross domestic product at current prices in Iraq reached 130.64 trillion dinars in 2009 compared to 157.03 trillion dinars in 2008, registering a contraction rate of $16.8 \%$ compared to a growth rate of $41 \%$ in 2008 , and this is due to the decrease in the value of oil exports resulting from the sharp decline in oil prices during mid-2008 and early 2009 (Al-Arabi, 2010, p.20). While the year 2011 recorded a growth rate of $34 \%$ to reach 217.33 trillion dinars compared to 162 trillion dinars in 2010, which is a higher growth rate than the $24 \%$ growth rate recorded in 2010 , which is mainly due to the increase in oil prices in international markets, its prices on the international markets increased by about $39 \%$ compared to 2010 , which was reflected in the increase in production and the increase in the value of exports (Al-Arabi, 2012, p.20). On the other hand, the years 2014 and 2015 witnessed a decline in the gross domestic product, registering a contraction of $2.7 \%$ and $27 \%$, respectively, as a result of the continued decline in oil prices in global markets, as the annual average of the spot price of OPEC crudes decreased from 96.3 dollars per barrel in 2014 to 49.5 dollars / Barrel in 2015, in addition to many political and economic challenges at the local, regional and global levels represented in the unstable political situation, the continued deterioration of the security situation and the military operations against terrorist groups that existed in the Iraqi governorates, which negatively affected the attraction of foreign investments to Iraq in general and the financial sector in particular, as a result of the high risk 
and uncertainty of the political, security and economic situation in Iraq (Al-Arabi, 2017). The years 2017 and 2018 witnessed a significant improvement and the pace of growth which increased supported by the convergence of external and internal conditions that were generally positive.

2- For the financial depth index, which is measured by dividing the market value in the stock market by the gross domestic product (Al-Fnennish, 2000, p 185), the market value index is used to measure the overall size of the market, which in turn is a measure of the country's ability to move capital The diversification of risks at the macro level as it shows the extent of the market's ability to contribute to supporting the economic growth process. This index is also used by many observers of the stock market as an indicator of the development of market activity. The higher the market value, this indicates an increase in economic activity, both in terms of the increase in the number of shares in the market or the increase in the number of companies in it, or in terms of the rise in market prices, which may be a reflection of the expansion of the volume of financial transactions in the market, or both (Al-Ani, 2002, p.61). This index alone cannot be completely relied upon as an indication for the degree of market development, as some markets are characterized by a high market capital ratio, while the

Table (2): The development of gross domestic product at current prices, market value and financial depth of the Iraq Stock Exchange

\begin{tabular}{|l|l|l|l|l|}
\hline Year & $\begin{array}{l}\text { GDP at current } \\
\text { prices } \\
\text { Trillion dinars( }\end{array}$ & $\begin{array}{l}\text { The rate of change } \\
\text { in GDP } \\
\%\end{array}$ & $\begin{array}{l}\text { Market value } \\
\text { Trillion dinars( }\end{array}$ & $\begin{array}{l}\text { Financial depth } \\
\%\end{array}$ \\
\hline 2006 & $\mathbf{9 5 . 5 8 8}$ & --- & $\mathbf{1 . 9 4 9}$ & $\mathbf{2}$ \\
\hline 2007 & $\mathbf{1 1 1 . 4 5 6}$ & $\mathbf{1 6 . 6}$ & $\mathbf{2 . 1 2 9}$ & $\mathbf{1 . 9}$ \\
\hline 2008 & $\mathbf{1 5 7 . 0 2 6}$ & $\mathbf{4 0 . 9}$ & $\mathbf{2 . 2 8 3}$ & $\mathbf{1 . 5}$ \\
\hline 2009 & $\mathbf{1 3 0 . 6 4 3}$ & $\mathbf{- 1 6 . 8}$ & $\mathbf{3 . 1 2 5}$ & $\mathbf{2 . 4}$ \\
\hline 2010 & $\mathbf{1 6 2 . 0 6 5}$ & $\mathbf{2 4 . 1}$ & $\mathbf{3 . 4 4 6}$ & $\mathbf{2 . 1}$ \\
\hline 2011 & $\mathbf{2 1 7 . 3 2 7}$ & $\mathbf{3 4 . 1}$ & $\mathbf{4 . 9 3}$ & $\mathbf{2 . 3}$ \\
\hline 2012 & $\mathbf{2 5 4 . 2 2 5}$ & $\mathbf{1 6 . 9 7}$ & $\mathbf{5 . 5 9 7}$ & $\mathbf{2 . 2}$ \\
\hline 2013 & $\mathbf{2 7 3 . 5 8 8}$ & $\mathbf{7 . 6}$ & $\mathbf{1 1 . 4 7 6}$ & $\mathbf{4 . 2}$ \\
\hline 2014 & $\mathbf{2 6 6 . 3 3 3}$ & $\mathbf{- 2 . 6 7}$ & $\mathbf{9 . 5 4 6}$ & $\mathbf{3 . 6}$ \\
\hline 2015 & $\mathbf{1 9 4 . 6 8 1}$ & $\mathbf{- 2 6 . 9}$ & $\mathbf{9 . 2 6 5}$ & $\mathbf{4 . 8}$ \\
\hline 2016 & $\mathbf{1 9 6 . 9 2 4}$ & $\mathbf{1 . 2}$ & $\mathbf{9 . 3 5 5}$ & $\mathbf{4 . 8}$ \\
\hline 2017 & $\mathbf{2 2 5 . 7 2 2}$ & $\mathbf{1 4 . 6}$ & $\mathbf{1 0 . 7 2 1}$ & $\mathbf{4 . 7}$ \\
\hline
\end{tabular}




\begin{tabular}{|l|l|l|l|l|}
\hline 2018 & $\mathbf{2 5 1 . 0 6 4}$ & $\mathbf{1 1 . 2}$ & $\mathbf{1 1 . 3 5}$ & $\mathbf{4 . 5}$ \\
\hline
\end{tabular}

Data revealed a positive relationship betweenthe movement of the gross domestic product and the level of financial depth during the period (2006-2018) as the fluctuations in the gross domestic product roughly parallel the changes in the market value, and this confirms the positive relationship that links the stock market indexes to the state of economic activity as shown in Figure (2):

Figure (2): Development of the gross domestic product at current prices, market value and financial depth of the Iraq Stock Exchange

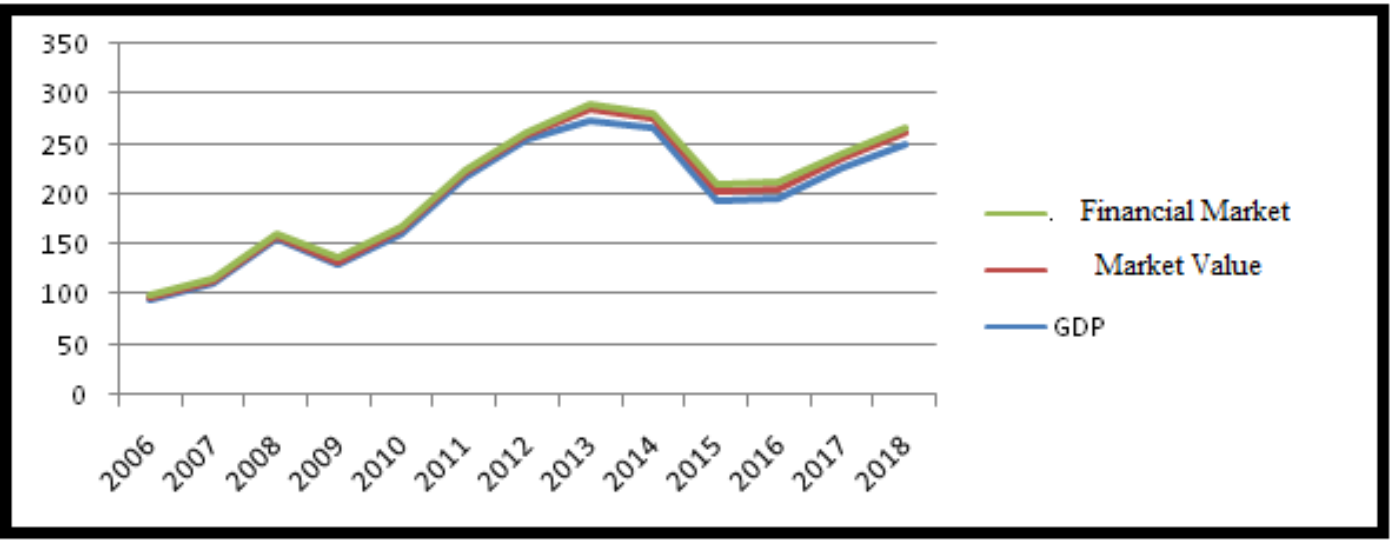

Source: Developed by the researcher based on the data in table (2)

\section{CONCLUSIONS :}

1-Financial globalization is an inevitable phenomenon that imposes itself by force and its goal is international integration and integration with the world, which has been shown to have great benefits or profits for the development of the financial system, but it may associate with many challenges or risks and shocks that affect the economies of countries in which financial liberalization measures are available, which must be guarded against.

2-Due to the activation of the Foreign Investment Law No. 13 of 2006, which allowed the entry of foreign capital into the country and the trading of shares of various foreign companies, the implementation of electronic trading activity and the activation of the market database, the shadows were reflected in the increase in the number of shares traded, and some developments in the work of the Iraqi Stock Exchange. However, the role of the market is still limited in the national economy due to the weak participation of the private sector in the market.

3-The number of foreign investors in the shares of the Iraq Stock Exchange is very limited, as a result of the recent experience of Iraq with regard to the functioning of stock markets and the absence of investment awareness, low income and the lack of a successful policy that encourages investment, in addition to the low rates of economic growth due to the economic and political instability in the country.

4-The companies listed on the Iraq Stock Exchange, which amount to (104) companies, and their market value is (11) trillion dinars, are weak companies, and the highest percentage in trading is for the banking sector, where the number of shares in this sector is 7.8 trillion shares, representing $72 \%$ of the market as whole, in other words, trading is concentrated in a small number of listed companies and this is an indication of the weakness of the 
effectiveness and activity of any financial market, and this does not help in attracting large numbers of foreign investors, in addition to the instability that made it possible that the investor would make a sudden decision to leave, so that this type of investment is often called hot money.

5-The Iraq Stock Exchange also witnessed weakness in the performance of the productive, industrial and agricultural sectors, in contrast to the dominance of the banking and communications sector in terms of trading size and the number of shares in the Iraq Stock Exchange, in addition to the weak performance of the banking sector as banking activity is concentrated in external transfer operations and trade finance, in addition to the absence of market-making institutions through investment funds, issuance houses, and banks that operate according to the concept of comprehensive banking that contribute to building joint-stock companies in cooperation with the private sector.

\section{RECOMMENDATIONS:}

1-Improving the efficiency of financial markets by strengthening the legal and regulatory frameworks that manage these markets, which are reflected in the increase in liberalization and openness with international markets towards liberal and effective Arab financial markets capable to attract foreign investments.
2-Increasing the supply and diversity of securities and investment tools by adopting the necessary legal procedures that encourage companies to list in the financial markets, and encouraging the listing of securities among the Arab financial markets, while increasing tax incentives for listed companies, in addition to introducing new financial instruments.

3-Increasing and enhancing the demand for securities, by increasing investment awareness in general, and establishing investment funds to attract less educated investors, in addition to increasing and activating the role of financial intermediaries institutions.

4-Protecting the rights of investors and maintaining market stability away from sharp fluctuations through the availability of adequate financial information regarding companies' activities and performance, while forcing listed companies to issue financial regulatory statements, especially those related to full financial disclosure.

5-Enhancing the role of financial markets in economic development by creating investment tools and opportunities to encourage savings and the return of expatriate investments, in addition to absorbing excess liquidity resulting from the high oil prices.

6-Contributing to achieving government privatization programs and diversifying the components of the gross domestic product.

\section{REFERENCES :}

1. M. Ayhan Kose, E. P.-J. (2007). Financial Globalization: Beyond the Blame Game. This article is based on IMF Working Paper No. 06/189, "Financial Globalization: A Reappraisal.", Finance and development, March 2007, Volume44,Number 1.

2. Michael Leahy, a. (2001). Contribution of financial system to growth in OCEDcountries. OCED, working papers n: 280 .

3. panit, L. (1998, INC.October). "the state in a changing world". world banks world development Report for 1997,monthly Review foundation .

4. Ross Levine, S. z. Stock Markets, Bank and Economic Growth. not published: World Bank.

5. Schmukler.S. (2004). " Financial globalization: gain and pain for developing countries”. Federal Reserve Bank of Atlanta economic review second quarter. 
6. Sergio L. Schmukler, P. Z.-L. (2001). Financial Globalization: Opportunities and Challenges for Developing Countries. Article - December 2001, See discussions, stats, and author profiles for this publication at: https://www.researchgate.net/publicatio.

7. Schmukler, S. L. (June 2004). Benefits and Risks of Financial Globalization: Challenges for Developing Countries. the World Bank Policy Research Report "Globalization, Growth, and Poverty," available at http://worldbank.org/research/b ,Development Research Group.

8. Mendoza . K, Q... (2009, October). "Financial globalization, financial crises and contagion”. National Bureau of Economic Research, Working paper 15432, Cambridge, .

9- Odalio Dantas (2002) Economic Globalization and Media Monopoly ( Globalization and its Impacts in the Arab Economy). Section6. Baghdad: Bait Alhikma.

10- Baul Kinidi (1993) Preparing for the $21^{\text {st }}$ Century. Beirut . Dar Alshorouq.

11- Hazem Al-Beblawy. (1998). The Role of the State Economy. Cairo: Dar El ShorouQ.

12. Hussein Abdul-Muttalib Al-Asraj. (2002). The role of the Stock Market in Developing Savings in Egypt. Unpublished MA Thesis, Department of Economics, Faculty of Commerce, Zagazig University.

13. Hameed Al-Jumaili. (2002). The Ideological Content of the World Trade Organization - An Analytical View of the Political Economy of Neoliberal Globalization. (Globalization and its impact on the Arab economy). Baghdad: Bait Alhikma.

14. Hanan Khaled Hanash Issawi. (2016). The Role of Indirect Foreign Investment in Revitalizing: the Iraq Stock Exchange and the Amman Market as a model. Unpublished MA Thesis - Al-Qadisiyah University - College of Administration and Economics.

15. Reda Abdel Salam. (2003). The Collapse of Globalization, the State Award-winning study in economics. The Arab Republic of Egypt: www.kotobarabia.com.

16. Iraq Stock Exchange. (2013). annual report.

17. Iraq Stock Exchange. (2015). annual report.

18. Iraq Stock Exchange. (2012). annual report.

19. Iraq Stock Exchange. (2006). annual report.

20-Salah Al-Din Muhammad Amin and Arshad Fuad Majeed. (2002). The role of banks in the stock market industry - an applied study and analysis. The Iraqi economy and Arab and international environment variables, Research and discussions at the third scientific conference of the Department of Economic Studies. Edited by Dr. Hana Abdul-Ghaffar Al-Samarrai and Dr. Imad Abdul-Latif Salem. Baghdad: Bait Alhikma.

21. Arab Monetary Fund. (2010). Consolidated Economic Report.

22. Arab Monetary Fund. (2012). Consolidated Economic Report.

23. Arab Monetary Fund. (2017). Consolidated Economic Report.

24. Taha Tayeh Al-Nuaimi. (2002). Scientific research and sustainable development in the conditions of globalization. (Globalization and its effects on the Arab economy). Baghdad: Bait Alhikma. 
25. Abdul-Muttalib Abdel-Hamid. (2001). Globalization and Banking Economics. Alexandria: University House for Books. 26. Imad Muhammad Ali Al-Ani. (2002). The merger of financial markets (The reasonsand its implications for the global economy). Baghdad: Bait Alhikma Publishing.

27-Muhammad Al-Fnennish. (2000). The financial sector in the Arab countries and the challenges of the next stage. Abu Dhabi: Arab Monetary Fund.

28. Madhar Muhammad Saleh. (2002). Globalization and national security: a critique of the saying "wealth and power in the perpetuation of the capitalist system". Baghdad symposium (globalization and its effects on the Arab economy). Baghdad: Bait Alhikma.

29- Yusef Ali Abdul-Asadi. (2004). Financial globalization and its implications for Arab economies. Unpublished PhD thesis, Basra University, College of Administration and Economics.

30. The Iraqi facts. (Date of Issue 8/31/1936). Issue1533.

31. The Iraqi facts. (Date of issue: 23 - 08 - 1943). Issue 2113.

32. The Iraqi facts. (Date of issue: 24 - 04 - 1971). Issue 1990.

33. Barry Johnson. (December, 1998). The Sequence of Actions to Liberate the Capital Account. Journal of Finance and Development.

34. Khaled Hussein Al-Sawaf. (2004). Stock markets in different Arab countries. Journal of the Faculty of Law - Nahrain University - Volume (6) - Issue (9).

35- Sassi Sufyan. (2004). Globalization is a challenge or a necessity. The Civilized Dialogue - Issue: 1020, Global Information Network, http://www.ahewar.org.

36. Abdul Amir Al-Saad. (2015) Globalization of developing financial markets in Algeria. Human Sciences Journal, No. 44. 